\title{
The Principle of Legality in Criminal Act of Terrorism*
}

\author{
Hariman Satria \\ Faculty of Law, University of Muhammadiyah Kendari \\ Jl. KH Ahmad Dahlan Nomor 10 Kendari \\ E-mail: hariman85antikorupsi@gmail.com
}

DOI: $\underline{10.15408 / \text { jch.v5i2.4959 }}$

\begin{abstract}
The trial of Imam Samudera cs uses Perppu No 12002 on Combating Criminal Acts of Terrorism. This regulation was made after Bali bombing 1. So the criminal provisions were made retroactively. Similarly, in cases of serious human rights violations in East Timor, the perpetrators use retroactive laws. Enforcement of the criminal provisions retroactively also made by the ad hoc international criminal court through Nurenberg Trial and Tokyo Trial in 1945. Enforcement of the criminal provisions aimed at fulfilling the principle of justice, that the convict by violating the principle of legality is not fair but not punishing guilty of serious crimes which did not fare much better. Strictly speaking, the principle of legality can be set aside.
\end{abstract}

Keyword: Principle of Legality, Criminal Act, Terrorism

* Received: June 14, 2017, Revised: July 12, 2017, Accepted: Agustus 22, 2017. 


\title{
Hariman Satria
}

\section{Asas Legalitas \\ Dalam Tindak Pidana Terorisme}

\begin{abstract}
Abstrak:
Peradilan kepada Imam Samudera cs, menggunakan Perppu Nomor1 Tahun 2002 tentang Pemberantasan Tindak Pidana Terorisme. Peraturan ini dibuat pasca peledakan bom Bali 1. Jadi ketentuan pidana dibuat surut. Demikian pula dalam kasus pelanggaran berat HAM di Timor Timur, para pelaku diadili di pengadilan HAM dengan menggunakan hukum yang berlaku surut. Pemberlakuan surut ketentuan pidana juga dilakukan oleh mahkamah pidana internasional ad-hoc melalui Nurenberg Trial dan Tokyo Trial tahun 1945. Pemberlakuan surut ketentuan pidana dalam tindak pidana terorisme ditujukan untuk memenuhi asas keadilan, bahwa memidana dengan melanggar asas legalitas memang tidak adil, tetapi tidak menghukum orang yang bersalah karena kejahatan berat yang dilakukannya jauh lebih tidak adil. Tegasnya demi principle of justice maka principle of legality dapat dikesampingkan.
\end{abstract}

Kata Kunci: Asas Legalitas, Tindak Pidana, Terorisme

How to cite (turabian):

Satria, Hariman. "The Principle of Legality in Criminal Act of Terro rism" JURNAL CITA HUKUM [Online], V olume 5 Number 2 (December 2017). 


\section{Introduction}

Almost all people in the world have already known or heard the word of "terrorism." This w ord is more popular when there are some many terrorism cases emerge in many countries in this world. The last case w as a suicide bomb case in French by a member of ISIS. He crushed himself to the bus and there was an accident and there was hundred more victim. ${ }^{1}$ Some people also believed that terrorism is a global phenomenon which is related to Politic need, thus sometimes the kind of this action depends on the condition and situation of each country. Furthermore, Claire de Than dan Edwin Shorts also stated that international terrorism has grow $\mathrm{n}$ in profile recent decades for a combination of reasons. ${ }^{2}$ Besides, of that terrorism also is an accumulation of some problems in a country that became a complicated situation. In addition, Secara Cindy C. Combs dan Martin Slann also described that terrorism is a phenomenon of international politics that has a long history and appears in a variety of forms. Terrorism's causes and manifestations are varied and complicated. ${ }^{3}$

Historically, the term terrorism originated in the French revolution during a period called Robespierre's Maximilien reign of terror. A period when people suspected of being government enemies were cruelly executed. ${ }^{4}$ So this term is more inclined to an attempt to finish off the government's political opponents. Almost same with the act of kidnapping and murdering a number of activists in Indonesia during the Orde Baru. Beside of that, the word terrorism is essentially older than the term. For example, the Assassins, a network associated with Shiite Muslim groups conventional in Iran, have committed acts of terrorism for over 1000 years ago. Three centuries before the Assassins, there was Thug of India, who routinely terrorized the people who traveled on the street ritually. ${ }^{5}$ It seems that in the last few decades, terrorism has continued to evolve by its followers. There has been an attempt by the terrorist group to survive in carrying out its mission and operations.

\footnotetext{
${ }^{1}$ pttp://www.bbc.com/indonesia/dunia/2016/07/160714 dunia nice serangan obama, retrieved on July $30^{\text {th }}, 2016$.

${ }^{2}$ Claire de Tpan and Edwin Sports, International Criminal Law and Human Rights (London: Sweet and Maxwell, 2003), p. 231.

${ }^{3}$ Cindy C. Combs and Martin Slann, Encyclopedia of Terrorism (New York: Facts on File Library, 2007), p. 13.

${ }^{4}$ Larry E. Sulliv an and Marie Simonetti Rossen, Encyclopedia of Law Enforcement-Volume 1, (London: Sage Publications, 2005), p. 457.

${ }^{5}$ Jimmy Gurule dan Geoffrey S. Corn, Principle of Counter-Terrorism Law (New York: West A Tpomson Reuters Bussines, 2011), p. 19.
} 


\section{Hariman Satria}

In the United States, the terrorist network has been operating in a long time. In 1970-1980's, Armenian terrorist groups did physical terror to Turkish officials and facilities spread across several cities in the United States. The terror finally killed the Consul General of Turkey in Los Angeles and Boston. This action was captured by the justice commandos for Armenian Genocide, an Armenian terrorist group that held a longstanding grudge against the Turkish government, due to the destruction of the Armenian population in Turkey. Not only in America, terrorist groups arealso known in the Middle East. Harakat alMuqawamah al-Islamiyya, a popular Palestinian group called Hamas (the Arabic word for "overflowing energy") is one of the groups that routinely acts of terror against America and its allies. ${ }^{6}$

The peak of terror activities occurred on September 11, 2001. At that time there was a twin tower event World Trade Center (WTC) and Pentagon in the city of New York, United States. Hundreds and even thousands of people, the majority of Americans must be dying for being the victim of barbarity perpetrators of the attack. Inevitably, this event is like a slap to the superpower state of the United States caliber because, in reality, the big sam country is a country that has advanced facilities when compared with other countries in the w orld. Not long after the warhead, Jorge W. Bush stated that the attacks on the WTC and the Pentagon were carried out by terrorist groups, under the command of Osama bin Laden. To prevent the recurrence of similar events, the United States government established a commission called The 9/11 commission report. The commission is assigned to conduct an in-depth investigation of the events of 11 September. The Commission concludes that the US is not ready for a sudden attack like terrorism. ${ }^{7}$

Terrorist groups also exist in other countries. In Pakistan, for example, there is a group called Tehreek-a-Taliban Pakistan. On December 16, 2014, the group stormed the army public school in the north-west of Peshawar city of Pakistan and massacred 148 people including 132 children. Not only in Pakistan, the Arabian Peninsula there are Al-Qaeda is commonly abbreviated as AQAP. This group was formed in 2006 from the merging of Yemen and Saudi Al-Qaeda wings on the Arabian peninsula. The group is believed to be one of the most dangerous groups of Al Qaeda. At this time other than to terrorize the territories in parts of Europe such as the incidence of Charlie Hebdo in France

6Jimmy Gurule dan Geoffrey S. Corn, Principle of Counter-Terrorism Law, p. 458.

${ }^{7}$ Cindy C. Combs and Martin Slann, Encyclopedia of Terrorism, p. 197. 
who allegedly trained from this group, they controlled most of the territory of Yemen. ${ }^{8}$

On the African continent precisely in Nigeria also a radical group known as Boko Haram. In 2005 they began a deadly massacre in Baga, a town in north-eastern Nigeria. According to international amnesty data, about 2000 people were killed. Last year Boko Haram abducted hundreds of students, including more than 200 children and they disappeared to this day. The group is reported to have used women and young girls as a "human bomb" in the attack. ${ }^{9}$ In addition to these groups, there are other terrorist groups that crime, violence, and brutality are not much different. Among these groups is Al Qaeda in Afghanistan, Hezbollah in Lebanon and ISIS in Syria-Iraq. ${ }^{10}$ In respect of the terrorism phenomenon Frank E. Hagan said that the views of the political context, international terrorism is an example of the worst mass murder in history. ${ }^{11}$

Still on the tragedy of terror, a year After the explosion of the WTC and Pentagon, precisely on October 12,2002, in Indonesia there was a similar event that was not even less devastating, namely the explosion of Paddys Café and Sari Club, at Jalan Legian, Kuta-Bali which became known as Bombing Bali I. the incident killed more than 200 (two hundred) people and injuring hundreds more. Among the victims are foreigners and most of them are from Australia and some from America. This incident prompted the United States and its allies like Australia, urging the Indonesian government to take seriously the events on that island. ${ }^{12}$

After that accident the government responded by establishing Law No. 1 of 2002 on Combating Terrorism Crime, a year later this law was upgraded through Act No. 15 of 2003 on Combating Terrorism Crime. This regulation is used to prosecute the perpetrators of the Bali bombing, namely Imam Samudra, Amrozi and Ali Gufron. Although it must be admitted the judicial process to Amrozi cs is contrary to the principle of legality because the rules used are applied retroactively. Whereas the far-away principle of legality (principle of

\footnotetext{
${ }^{8}$ Cindy C. Combs and Martin Slann, Encyclopedia of Terrorism, p. 184.

${ }^{9}$ www.tempo.co.id, 10 (sepuluh) Organisasi Teroris Paling Berbahaya di Dunia, Retrieved from the internet on March 20th, 2015.

${ }^{10}$ www.tempo.co.id, 10 (sepuluh) Organisasi Teroris Paling Berbahaya di Dunia, Retrieveid from the internet on March 20th, 2015.

${ }^{11}$ Frank E. Pagan, Introduction to Criminology: Theories, Methods, and Criminal Bepavior (London: Sage Publication, 2012), p. 530.

12 Dani Krisnawati, et.al, Bunga Rampai Hukum Pidana Khusus (Jakarta: Pena Ilmu dan Amal, 2006), p. 21.
} 


\section{Hariman Satria}

legality) has given a warning about the prohibition of retroactiveness of a criminal provision. ${ }^{13}$ The urgency principle of legality by Moeljatno described as a reaction to the absolute pow er of absolute authority so that every act must be determined in advance in the law so that everyone knows before the perpetrator is convicted. However, although it is considered to violate the principle of legality thejudicial process to perpetrators is still carried out which in the end they are sentenced to death penalty. The question then is whether in the criminal act of terrorism the existence of the principle of legality can be miss used?

\section{Terrorism: The Idea Contestation}

W.J.S. Poerwadarminta said that terror or terrorism is the practice of acts of terror that is the use of violence to cause fear in an effort to achieve a goal (especially political goals). ${ }^{14}$ Nevertheless, recently the development of terrorism is pushed more by other issues than political objectives. This was stated by Gennaro F. Vito and Ronald M. Holmes, terrorism has increased for reasons other than political issues. ${ }^{15}$ Although political issues are diminishing in the terrorism crime basically there is still a close relationship between the two. This issue can be seen from the definition of terrorism put forward by Sanford H. Kadish, terrorism as the threat of terrorism. Or intimidate a target group wider than intimidating victims. ${ }^{16}$

Aligned with Kadish's, Brian Jenkins also defined terrorism as a use or threat of violence, aimed at achieving political change. Explicitly outlined by Jerkins, terrorism is the use or threatened the use of force designed to bring about political change. ${ }^{17}$ While in another hand, Richard A. Wright and J. Mitchel Miller who stated that terrorism is the unlawful use of force and violence against persons or property to intimidate or coerce a government, the civilian population, or any segment thereof, in furtherance of political or social

${ }^{13}$ Moeljatno, Asas-Asas Pukum Pidana, (Jakarta: Rineka Cipta, 2008), p. 26.

14 W.J.S. Poerwadarminta, Kamus Umum Bahasa Indonesia (Jakarta: Balai Pustaka, 1990), p.

1263.

15 Gennaro F. Vito dan Ronald M. Polmes, Criminology: Theory, Research, and Policy (California: Wadsworth Publishing Company, 1994), p. 289.

16 Sanford P. Kadisp, Encyclopedia of Crime and Justice (New York-London: The Free Press Collier Macmillan Publishers, 1983), p. 1530.

17 Brian Jenkins, International Terrorism: A New Kind of Warfare, Santa Monica: Rand Corporation), 1974), p. 200. 
objectives. ${ }^{18}$ Thus, terrorism is an act of violence - designed to instill fear among civil society as a continuation of political or social objectives.

Based on some of the definitions mentioned above, both proposed by Poerwadarminta, Kadish, Wright, and Miller, and Brian Jenkins then we can say that when talking about terrorism then at least there are some essential elements. First, terrorism is an action taken by violence or threat of violence. Second, the violence is against the law and is aimed at instilling fear. Thirdly, violence directed at a person or group or to property or public facilities. Fourth or last, the main address of acts of terror is for political or social interest in the view point of terrorists.

The concepts of terrorism which are described above are doctrinal perspectives, which are more likely to be based on opinions expressed by jurists in analyzing the crime of terrorism. It is known that doctrine is one of the most recognized legal sources of existence in the universe of jurisprudence including international law. ${ }^{19}$ So the existence of doctrine on terrorism becomes very important to help provide a holistic understanding, as well as complement the shortcomings of other sources of law such as law. The normative concept of terrorism is regulated in Article 1 point 1 of Law Number 15 the Year 2003 on the Eradication of Criminal Acts of Terrorism, the act of terrorism is all acts that fulfill the elements of a crime in accordance with the provisions in the Government Regulation in lieu of Law. Taking into consideration the formulation of the quo rule does not in any way explain the concrete definition of terrorism but emphasizes acts which can be categorized as part of a terrorist act. So explicitly the quo rules lead us to further read some of the articles in it relating to the crime of terrorism. The articles include Articles 6 to 19 .

Still on the crime of terrorism, to be more easily recognizable then this criminal act is considered to have its own characteristics when compared with other criminal acts. Nettler identifies six characteristics of terrorism. First, no rules: terrorist differ from soldiers and police and that they consciously violate all convention. Second, no innocent: terrorist fight the unjust system which includes all people within that system who do not side with them. Third, economy: terrorist frighten tens of thousands even millions of people by a single act. Fourth, publicity: terrorist seek publicity, which in turn encourages more terrorism. Well-publicized violence advertises that terrorist cause. Fourth,

18 Richard A. Wright dan J. Mitchel Miller, Encyclopedia of Criminology, (New York: Routledge Taylor and Francis Group, 2005), p, 1640.

${ }^{19}$ M. Cherif Bassiouni, Introduction to Interna tional Criminal Law (New York: Transnational Publishers Ardsley, 2003), p., 4. 


\section{Hariman Satria}

publicity: terrorist seek publicity, which in turn encourages more terrorism. Well-publicized violence advertises that terrorist cause. Fifth, individual therapy: terrorist find their acts to be enjoyable or therapeutic. Fighting for a just cause gives purpose to living that is otherwise meaningless. Sixth, varied objective: terrorist seek to acquire and to exercise power, although different members of the group may have different ideas about what the power should be used for. ${ }^{20}$

Although it is not mentioned as a characteristic of terrorism, it has actually become part of the criminal act of terrorism itself. In other words, when we discuss the particulars of terrorist characteristics mutatis mutandis implicitly related to the characteristics of the crime, in this case, the criminal act of terrorism. In parallel with it, Andi Hamzah mentions four characteristics of terrorism. First, by force that generally uses firearms or explosives aimed at the loss of life or damage to property. Second, do not choose or separate potential victims who are considered enemies or not. Third, there is no sense of humanity. Fourth or last, although acting in the name of a religion, his actions are not in accordance with that religion. ${ }^{21}$ Both the concept of Hamzah and Nettler both have the same essence.

In simple terms, the characteristics of terrorism are then described by William J. Chambliss and Aida Y. Hass who say that to qualify an act as a terrorist or not can be seen on four things. First, intent to coerce intimidate or convey some message to an audience beyond the immediate victims. Second, be aimed at attaining a political, social, religious, or economic goal. Third, occur outside the context of legitimate warfare. Fourth, be outside the scope of the humanitarian law..$^{22}$ Referring to the concepts put forward by Hamzah, Nettler and the Chamblis-Hass, we can conclude that the characteristics of terrorism or the crime of terrorism basically include six things. First, his actions are deliberate and use force to intimidate one's psychology or the public. Second, its actions violate national law and international law. Third, the motive of his actions is based on certain political, social or religious interests. Fourth, the perpetrators of criminal acts of terrorism are indoctrinated to enjoy the crime they committed so as not to have a moral burden to the victim as well as the fear of the state apparatus. Fifth, terrorist attacks are aimed at providing economic benefits because only one attack carried out by a person can

${ }^{20}$ Gennaro F. Vito dan Ronald M. Holmes, Criminology: Theory, Research, and Policy, p. 289.

21 Andi Pamzap, Perundang-Undangan Pidana Tersendiri-Nonkodifikasi (Jakarta: PT Sofmedia, 2014), p. 229.

22 William J. Cpambliss dan Aida Y. Pass, Criminology: Connecting Theory, Research, and Practice (New York: McGraw-Pill, 2012), p. 362. 
intimidate or intimidate thousands or millions of people. Sixth, in every act, terrorists try to publish or propaganda which in turn will stimulate many people to empathize with them.

Looking at the concept of terrorism and its characteristics, it seems from the beginning that this crime is intentionally not strictly defined because it has many tangents, especially politically and criminally. In international law, it is not given a specific concept of terrorism but globally. Seeing this fact Ilias Bantekas and Susan Nash say the term terrorism is commonly and widely used in everyday parlance with varying political and criminal connotations but the same time it remains a designation which is elusive and one that has never been singly defined under international law, at least at the global lev el. ${ }^{23}$

Furthermore, the crime of terrorism, when saw from international law, this crime in principle is a crime under international law. Romli Atmasasmita by quoting Edward M. Wise outlines that terrorism is one of the crimes of three types of international crime. The other two types as part of the crime of terrorism are hijacking, crimes against persons receiving international protection and convention on hostages. ${ }^{24}$ Different opinions expressed by Dautricourt, who still doubt the existence of terrorism and hijacking in the eyes of the international law as an act that can be called delicate juris gentium or not. ${ }^{25}$

Answering Dautricourt doubt then Dani Krisnw ati et.all, described that the subject of hijacking as one form of terrorism cannot be separated by 3 (three) international conventions related to hijacking. First, the Tokyo convention, September 14, 1963, on offenses and certain other acts committed on board aircraft (aircraft robbery). The Convention determines that the crimes committed in an aircraft but does not specify when airborne aircraft shall be declared under international law. Second, the Hague Convention, December 16, 1970, regarding the for suppression of hijacking. One of the key points of this covert-operation is to establish hijacking as an international crime with universal jurisdiction. Third, the Montreal Convention, September 23, 1971, concerning the supremacy of unlaw ful acts of the safety of civil aviation.

In this Convention, it is qualified as hijacking anyone intentionally by unlaw fully committing acts of violence against persons in flight, if such acts

23 llias Bantekas and Susan Nash, International Criminal Law (New York: RoutledgeCavendish, 2007), p. 195.

${ }^{24}$ Romli Atmasasmita, Pengantar Hukum Pidana Internasional (Bandung: Refika Aditama, 2003), p. 44.

${ }^{25}$ Romli Atmasasmita, Pengantar Hukum Pidana Internasional, p., 45. 


\section{Hariman Satria}

could endanger the flight. Still, according to the convention, hijacking qualification is placing explosives inside the aircraft or attempting to act or become an accomplice of the person conducting the experiment. ${ }^{26}$ The other important point in this convention is an extension of the in-flight understanding. At first, the definition is in flight when the passengers are onboard but his understanding was expanded not only in flight alone but also in service. This means that since the plane prepared by the ground crew for a specific flight. 27

The authors' comments, if the three conventions are noticed carefully, then a significant development in regulated legal matters is likely to be widespread. The Tokyo convention regulated is a crime committed on board aircraft, while Denhaag's convention is concerned with a matter called "aircraft control". Furthermore, the Montreal convention, because it regulates the problem of actions on aviation, which is not only the act of mastering aircraft but also acts that endanger the safety of aviation in general, such as acts of sabotage.

Furthermore, related to the hijacking that is qualified as part of the crime of terrorism, in fact, it is undoubtedly the existence of whether the crime is a delicate juris of gentium or not. If the starting point is delicta juris gentium as a common international crimestandard then it is difficult for crime hijacking to be qualified as an international crime. However, considering the fact that currently terrorists and hijackers are easily crossing the boundaries of the jurisdiction of a state, the facilities used by the perpetrators, in fact, involve more jurisdiction than state stau plus the victims who come from various countries then it seems appropriate if the crime is determined as an international crime. Thus against terrorism or hijacking, its eradication must be carried out by each country in accordance with the universal principle. When using the universal principle then at that time also the principle of delicta juris gentium applicable because the prosecution of the perpetrators of crime no longer relies on the principles of national criminal law such as the territorial principle of therapy has been using the principle of extraterritorial.

In its development, not only hijacking is qualified as terrorism but also piracy of ships (piracy). As confirmed in the Convention for The Suppression of Unlawful Acts Against The Safety of Maritime Navigation (1988-Applies to Terrorism Actions on Ships) states, international aviation. Still according to the

26 Dani Krisnawati, et.al, Bunga Rampai Hukum Pidana Khusus, p. 228-229. Bandingkan dengan Sudarto, Kapita Selekta Pukum Pidana, (Bandung: Alumni, 2006), p. 6.

27 Eddy O.S Pairiej, Pengantar Hukum Pidana Interna sional, (Jakarta: Erlang ga, 2009), p. 65. 
convention terrorism is defined as, make it offensive for a person unlaw fully and intentionally to seize or exercise control over ship by force, threat or intimidation; to perform an act of violence against a person on board a ship if that act is likely to endanger the safe navigation of the ship; to place a destructive device or substance abroad a ship; and other acts against the safety of ship. ${ }^{28}$

Another crime that is also qualified as terrorism is a crime against people who receive international protection. The subject of crimes against protected persons is expressly stipulated in the Convention on the Prevention and Punishment of Crimes Against International Protected Persons 1973 (Outlaws Attacks on the Senior Government Officials and Diplomats). The contents of such convention include the mention of internationally protected persons as Heads of State, Foreign Ministers, Representatives or officials of an international organization entitled to special protection from assault under the international law. ${ }^{29}$ Regarding this protection is in fact closely related to the principle of par in parem in hebet imperium in international criminal law. That is a head of state violates the law in another country then the head of state is punished by using the law of his country.

In Contrary, we can say that the Head of State cannot be punished by using the laws of other countries. However, this principle can be disrupted if the head of state committed serious crimes against human rights such as genocide, crimes against humanity and war crimes. ${ }^{30}$ But regardless of such exceptions, how ever, it can be concluded that this preferential treatment serves as a form of protection to the head of state.

\section{Enforcement of Criminal Provisions}

Talking about the enactment of retroactively criminal provisions cannot be separated from the principle of legality. Historically, the principle of legality w as first constructed by Anselm von Feuerbach (1775-1833), a German criminal law scholar in his book Lehrbuch des penlichen recht in 1801. At that time he was guided by three Latin adugia namely nulla poena sine lege; nulla poena sine crimen and nullum crimen sine poena legal. The third adugium was then formulated by Feuerbach into the principle of nullum delictum, nulla poena

\footnotetext{
${ }^{28}$ llias Bantekas and Susan Nash, International Criminal Law, p. 178.

${ }_{29}$ M. S pokry El-Dakkak, State's Crimes Against Humanity: Genocide, Deportation and Torture form The Perspectives of Interna tional and Islamic Laws (Kuala Lumpur: A.S. Nordeen, 2000), p., 120.

${ }^{30}$ Read an Article 27 International Criminal Court (ICC) 1998.
} 


\section{Hariman Satria}

sine praevia lege meaning no criminal act, no criminal without provisions of the law. ${ }^{31}$ This principle is then mentioned in Article 1 paragraph 1 of the Indonesian Criminal Code, which can be called the principle of legality. Dupont said that the principle of legality is one of the most important principles of criminal law. Affirmed by Dupont, het legalitasbeginsel is een van de mest fundamentele bginselen van het strafrecht. ${ }^{32}$

The formulation of the legality principle undertaken by von Feuerbach is basically related to his teachings known as vom psycologischen zwang theory that in order to determine the actions that are prohibited in the rules, not only about the actions that must be written clearly but also concerning the type of threatened penalty. In this way, the person who will do the forbidden deed, first know what criminal will be imposed on him if later deed is done. ${ }^{33}$ When traced more back again, von Feuerbach theory is based on the idea of crime prevention efforts that have been done for centuries. The prevention of this crime refers to the latent adatium expressed by Plato in Greek philosophy, which reads: nemo prudens punit, quia peccatum, sed ne peccetur means a wise person does not punish for sin, but not $\sin .{ }^{34}$ The essence of von Feuerbach's teachings is the existence of psychological coercion (scare) which is a criminal penalty for those who commit crimes.

Back on the principle of legality, Moeljatno proposed three meanings contained in it: first, no action is prohibited and threatened with a crime if it had not been declared in a legislation before. Second, to determine the existence of a criminal act should not be used analogies. Third, the rules of criminal law do not apply retroactively. ${ }^{35}$ Meanwhile, according to Groenhuijsen, there are four meanings of the principle of legality. First, that lawmakers should not enforce a criminal convention in retrogradelaw. Second, that all prohibited acts must be formulated in the clear formulation of offense. Third, judges are prohibited from declaring that the defendant commits a criminal offense based on an unw ritten law or customary law. Fourth, the criminal code is prohibited

31 D. Scpaffmeister, N. Keijzer dan E.PP. Sutorius, hukum Pidana: Kumpulan Bapan Penataran hukum Pidana Dalam Rangka Kerjasama hukum Indonesia-Belanda (Yogyakarta: Liberty, 1995), p. 5.

32 Komariap Emong Sapardjaja, Ajaran Melawan Hukum Materil dalam hukum Pidana Indonesia: Studi Kasus tentang Penerapan dan Perkembangannya dalam Yurisprudens, $i$ (Bandung: Alumni, 2002), p. 6.

33 Moeljatno, Asas-Asas Pukum Pidana, p. 27.

34 Jan Remmelink, hukum Pidana: Komentar a tas Pasal-Pasal Terpenting dari Kitab UndangUndang Hukum Pidana Belanda dan Padanannya dalam Kitab Undang-Undang Pukum Pidana Indonesia (Jakarta: Gramedia Pustaka Utama, 2003), p. 605.

35 Moeljatno, Asas-Asas Hukum Pidana, p. 27-28. 
from using an analogy. The first two meanings are addressed to the legislator while the latter tw o meanings are the guidelines for the judge. ${ }^{36}$

A similar opinion was expressed by Jescheck and Weigend, as quoted by Machteld Boot stated, "The formulation of the Gesetzlichkeitsprinzip in Article $1 \mathrm{StGb}$ is generally considered to include four separate requirements. First, conduct can only be punished if the punishability, as well as the accompanying penalty, had been determined before the offense was committed (nullum crimen, noela poena sine lege praevia). Furthermore, these determinations have to be included in statutes (Gesetze): nullum crimen, noela poena sine lege scripta. These statutes have to be definite (bestimmt): nullum crimen, noela poena sine lege certa. Lastly, these statutes may not be applied by analogy which is reflected in the axiom nullum crimen, noela poena sine lege stricta".

In short, speaking of the principle of legality is related to the four Latin adaptations of Jescheck and Weigend. First, nullum crimen, noela poena sine lege praevia or lex praevia means no criminal act, no criminal without previous law. Consequently, criminal provisions shall not be retroactive. Second, nullum crimen, noela poena sine lege scripta or lex scripta means no criminal act, no criminal without a written law. The effect is a prohibited criminal activities including the criminal threat must be expressly written in the law. Third, nullum crimen, noela poena sine lege certa (lex certa) means no criminal act, no criminal without clear rules of law. The consequence is that the formulation of a criminal act should be clear, so as not to be multi-interpretive so as to jeopardize legal certainty. Fourth, nullum crimen, noela poena sine lege stricta (lex stricta) means no criminal act, no criminal without strict law. That implicitly does not allow analogy. Criminal provisions should be strictly interpreted to prevent new criminal acts. ${ }^{37}$

Still, on the principle of legality, Schaffmeister, Keijzer, and Sutorius reveal two functions on the principle that the function of protecting the instrumentation and function. Function protect inter preted that criminal laws to protect people against the exercise of power without limits from the government or protect people from arbitrary agents. While the function of

\footnotetext{
${ }^{36}$ Komariap Emong Sapardjaja, Ajaran Melawan Hukum Materil dalam Hukum Pidana Indonesia: Studi Kasus tentang Penerapan dan Perkembangannya dalam Yurisprudensi, p. 5-6.

37 Eddy O.S. Piariej Eddy O.S. Piariej, Asas Legalitas dan Penemuan Hukum Dalam Hukum Pidana, p. 4-5. Compare it to Macpteld Boot, Op.Cit, p. 95-100.
} 


\section{Hariman Satria}

instrumentation is within the limits prescribed by law, the exercise of pow er by the government expressly permitted. ${ }^{38}$

Of the several meanings of the legality principle which he has reviewed above, specifically to be discussed in this section is the prohibition of retroactiveness of a criminal provision (nullum crimen, noela poena sine lege praevia). Regarding this matter, in Germany which in fact the place where the principle of legality was born, ever imposed retrograde or retreat criminal provisions. Bambang Poernomo described it so, in Germany in 1933 Law No. 29 of 1933 stipulated that the law was retroactive until 31 January 1933 as a regulation to protect the interests of the people and the state. To Marine van de Lubbe and his friends who were indicted for burning Reuchtstaatgebow (mayor's office) on 27 February 1933 w as heavily penalized under the law. This event came to be known as lex, van de Lubbe. ${ }^{39}$ In short, Germany under the leadership of Hitler Nazi was the first time a penal provision was applied retroactively on the grounds of protecting the interests of the people and the state.

Not only in Germany, the Dutch Indies government in Indonesia has issued Ordinantie 22 September 1945 - 35 valid on 7 October 1945, contains provisions in Articles 18 and 19 that this Ordonantie ${ }^{40}$ shall be in effect withdrawn until 10 May 1940 and Article $1 \mathrm{WvS}$ is not enforced or not incurred against this Ordonantie. It seems that the imposition of retroactive criminal provisions by the Dutch government is different from that in Germany. The Dutch Hindu government imposed a retreat of law in order to remain in power in the territory of Indonesia and perpetuate the WvS they carried while in Germany more inclined to create the status quo. Referring to the above reviews, we can say that both in Germany and in Indonesia (Dutch Indies), the principle of legality has been disrupted by the retroactiveness of a criminal provision, albeit with different motives from each other.

As the authors have described in the introduction, in Indonesia the scent of retroactive enforcement of criminal provisions has also been made in the Bali bombing incident in 2001 with the accused Imam Samudra, Amrozi and Ali Gufron. All perpetrators are tried by using Perppu No. 1 of 2002 on Combating Terrorism Crime. This means that the Perppu as a basis to prosecute the perpetrators applied in retroactivity. There is no logical ratio from the

${ }^{38}$ D. Scpaffmeister, N. Keijzer dan E.PP. Sutorius, Hukum Pidana: Kumpulan Bahan Penataran hukum Pidana Dalam Rangka Kerjasama Pukum Indonesia-Belanda, p. 4.

${ }^{39}$ Bambang Poernomo, Asas-Asas hukum Pidana, (Jakarta: Gpalia Indonesia, 1993), p. 71.

${ }^{40}$ Bambang Poernomo, Asas-Asas Hukum Pidana, p., 72. 
government that can be accepted by all parties related to the enforcement of this penal provision. Other cases whose penal provisions have also been applied retroactively are Abilio Jose Osorio Soares, Eurico Baros Gomes Gutteres, and Adam Damiri. At that time Soares, Gutteres, and Damiri were tried in a human rights court charged with gross human rights violations in East Timor. Nevertheless, the defendants or their attorneys reject the indictment on the grounds that the process is contrary to the principle of legality because the Human Rights Court Act was made after the event of chaos in East Timor (Timor Leste). This objection was rejected by the human rights court while claiming that the court was authorized to prosecute the perpetrators.

In the context of international criminal law, the enforcement of a criminal stipulation has also been imposed in the Nurenberg Trial or London Charter, in 1945, the trials made by allies as winners of war to Nazi German military leaders. The criminal provisions imposed on the German war leadership were made in full force by the Nuernberg Court. Therefore, the defendant argued that the judicial process to them it is not fair because it violates the principle of legality by imposing retroactively a criminal provision. ${ }^{41}$ However, the judges in the Nuernberg Court rejected the arguments of the accused and said that the convict in violation of the principle of legality is not fair but did not punish the guilty for a crime he did much more unfair. ${ }^{42}$

A similar incident was repeated at a Tokyo court or Tokyo Trial (International Military Tribunal for the Far East, 1946). The trial was shaped by allies with the aim of prosecuting Japanese war leaders shortly after their defeat in the Second World War. The defendants on trial reject the judicial process by reason of violating the legality principle of applying the ex-post facto law or enforcing retroactiveness of criminal provisions. But the panel of judges held differently, that the prohibition of the retroactive enforcement of criminal regulations was related to the expression of a politically disagreeable policy in international law. This prohibition can be ignored by the holder of power if circumstances require especially in the war of independence. ${ }^{43}$

${ }^{41}$ Eddy O.S. Piariej Eddy O.S. Piariej, Asas Legalitas dan Penemuan Hukum Dalam Hukum Pidana, p. 75-76.

${ }^{42}$ Eddy O.S. Piariej Eddy O.S. Piariej, Asas Legalitas dan Penemuan Hukum Dalam Hukum Pidana, p. 77.

43 Macpteld Boot, Nullum Crimen Sine Lege and the Subject Matter Jurisdiction of the International Criminal Court: Genocide, Crimes Against Humanity, War Crimes, p. 198. 


\section{Hariman Satria}

Based on the review above, it can be concluded that neither at the national court level nor the ad hoc international criminal tribunal, the principle of legality is substantially disrupted through the enforcement of a criminal law. Such retroactiveness is related to the fulfillment of justice for the victims and the state due to the crimes perpetrated by the perpetrators. The crime is a gross violation of human rights as well as criminal acts of terrorism. Both of these crimes are passive victims, so it can cause injustice if only fixated on the principle of legality because the perpetrators have committed crimes that are very harmful to both material and immaterial, even though the state participated harmed. Therefore, the application of retroactive criminal provisions can be accepted with the aim of upholding justice. Although it is also hard to deny that there is political content in international criminal tribunals such as the Nurenberg Trial and Tokyo Trial, it is another.

Strictly speaking, with the aim of upholding justice, the criminal justice process to serious perpetrators of crimes, such as terrorism and human rights crimes - the existence of the principle of legality can be disregarded. This reason also derives the empirical justification of Gustav Radbruch later known as radbruch's formula, essentially saying that the positive law (Law) is considered as opposed to justice and can not be applied if there is an inconsistency between law and justice. It is plainly stated by Radbruch, a positive law must be regarded as contrary to justice and not applied where the inconsistency between statute law and justice is so intolerable that the former must give way to the latter. ${ }^{44}$ The point in Radbruch's view is that there is legal justice versus legal certainty. Therefore John Rawls says, analogously, an injustice is tolerable only when it is necessary to avoid an even greater injustice. ${ }^{45}$ Injustice is justified to prevent greater injustice. For that reason, Rawls, again reminded that being first virtues of human activities, truth and justice are uncompromising. ${ }^{46}$

\section{Revision of Anti-Terrorism Law: Perspective of Ius Constituen dum}

At this time the government is discussing the revision of the AntiTerrorism Act as a change of Law Number 15 the Year 2003 on the Eradication

44 Antonio Cassese, International Criminal Law (New York: Oxford University Press, 2003), p. 141 .

45 John Rawls, a Theory of Justice, (Massachusetts - New York: Harvard University Press, 1999), p., 4.

46 John Rawls, a Theory of Justice, p., 4. 
of Criminal Acts of Terrorism. This change is believed to be a response to the increasingly widespread terrorism crime in Indonesia on the one hand but on the other hand, it is believed there are still some weaknesses found in a quo regulation. Based on the evolving discourse, there are 10 (ten) additional articles with details of 9 (nine) change articles and 1 (one) article of removal which is the focus of the revision. Associated with the formulation of criminal acts, in principle still, follow the old model of dividing the criminal law material and criminal law formal. The penal law is related to several acts. First, the ownership, trade, and distribution of explosives for terrorism (Article 10A). Second, the recruitment of members of terrorism (Article 12A). Third, hate speech related to terrorist activities (Article15A). Fourth, revocation of passport and loss of citizenship (Article 16). While the formal criminal law includes several things as well. First, extend the authority of the arrest to 30 days (Article 28). Second, the examination of witnesses of long-distance communications (Articles 32 and 34A). Third, protection of law enforcement officers (Article 33). Fourth, terrorist deradicalization maximum 6 (six) months in the form of identification, rehabilitation, reeducate and resocialize. ${ }^{47}$

The author's commented regarding the anti-terrorism bill are as follows: first, it seems that the drafting team of the bill wants to combine law enforcement and human rights protection on the one hand but on the other hand there is no attempt to legalize the domination of state repressive actions against alleged people become part of a terrorist group. This is somewhat risky because it will trigger the emergence of abuse of authority (abuse of power) state apparatus. Ideally, as far as possible the state can balance between the interests of law enforcement and the protection of human rights simultaneously. Second, when viewed in the perspective of the criminal justice system, the Bill seeks to combine the crime control model and the due process model ever conceived by Herbert L. Packer. In the crime control model implicitly prioritizes speed so that criminal behavior must be dealt with immediately and the suspect is left until he himself is doing the fight. While in due process model likened to the person who was doing hurdle. In essence, both models have competing values but not opposite. ${ }^{48}$ In fact, when referring to the bill, an alleged ter rorist with a crime control model approach will be dealt with immediately until he himself takes the fight, normatively this indication can be seen in Article 28 in Article 33 of the Bill. Whereas in the context of a due

\footnotetext{
${ }^{47}$ Indriy anto Seno Adji, Revisi UU Terorisme, Penegakan Pukum dan Perlindungan PAM, KOMPAS Sunday, July 17th, 2016.

48 Pebert L Packer, Tpe Limits of tpe Criminal Sanction, (New York:Oxford University Press, 1968), p. 151-153.
} 


\section{Hariman Satria}

process model, an alleged terrorist is processed by upholding human rights, promoting the principle of presumption of innocence.

Third, Form of Law also seeks to combine aspects of punishment as retributive (repressive) and deterrence (deterrence-preventive). Theoretically, a penalty with emphasis burden is a classical criminal law product with the aim of protecting individuals from the arbitrariness of the state. But at this moment there has been a shift towards a modern criminal law that protects the state from evil. Even the word Muladi suitable model used especially in Indonesia is referring to daad-dader strafrecht or the balance of interest models. This model is more realistic because it takes into account the various interests that must be protected by criminal law that is the interests of the state, individual interests, public interest, interests of the perpetrators and interests of victims of crime. ${ }^{49}$

Fourth, the concept of deradicalization. This concept seems to be more prone to preventive or preventive efforts with an emphasis on identification, rehabilitation, re-education, and resocialization. This means that suspected terrorists will be placed in the context of deradicalization with a maximum duration of 6 (six) months. An important point to emphasize is that the government should clarify the meaning of deradicalization, pointing to which organizations are forbidden - are considered affiliated with terrorists, so they are easily identified. The obvious mention in the perspective of the legality principle is concerning the adugium nullum crimen, noela poena sine lege certa (lex certa) that the criminal regulations should clearly provide arrangements. The aim is to avoid abuse by apparatus about people who can be categorized terrorists so that it is radicalized.

In addition, when linked with the current developing discourse - there are still some interesting things commented on. First, an indication of Indonesian army involvement in the prevention and eradication of terrorism. If this formulation is maintained it implicitly gives the message that the government no longer trusts the police (Densus) and BNPT to combat terrorism. In addition, Indonesian Army involvement will be very dangerous for the continuity of the current system of democracy because according to the history of it was faced with the power of civil society due to arbitrary and authoritarian actions. Second, a further concern is that the excesses of the policy will lead us back to the time of entry into force of the subversion law. This regulation is used by the authorities to perpetuate its power by exhausting all

49 Muladi, Kapita Selekta Sistem Peradilan Pidana (Semarang: Badan Penerbit Universitas Diponegoro, 1995), p. 15. 
activities allegedly contrary to the interests of the rulers including radical fundamentalist groups. Not only that, the regulation was also used to withstand political opponents of the government without judicial process or even if there was a judicial process carried out in a manner far from the rule of law.

Third, the act of terror is included in the realm of criminal law and criminal procedure law. Perspektive criminal procedural law any violation of the criminal law will be dealt with using the authority of each law enforcement agencies. Therefore KUHAP explicitly introduces the principle of functional deferenceation which is a separation of the authority of each law enforcement agency: police as an investigator, prosecutor, and judge as a breaker. Thus the involvement of the TNI or intelligence in the fight against terrorism is counterproductive with the principle of functional defensins. Fourth, the government has not clearly defined and measured what is called terrorism. This will have implications for its implementation in the field, it is not possible that the impression that something is not there is made up. In this case a person or a group that is not really a part of a terrorist but as opposed to a government interest, they are easily labeled as terrorists. Mark M. Lanier and Stuart Henry, have warned of the danger of labeling someone as a criminal. It is said by Lanier and Henry labeling theorists are concerned with the failure of socialization. However, instead of focusing on bonds, they examine the social reaction component of interaction with society's control agents. ${ }^{50}$

\section{Conclusion}

Based on the description above, there are several things that can be concluded in this paper. First, talking about terrorism is a social phenomenon that has strong relations with certain political, social and religious interests in a country. Therefore, jurists call the characteristics of terrorism are always dodged and with a political crime. Second, in Indonesia, the crime of terrorism has been regulated through goverment Law No. 1 of 2002 jo Law Number 15 the Year 2003 on Eradication of Criminal Acts of Terrorism. However, in the case of the Bali bombing 1, the judicial process to the perpetrators was done by violating the principle of legality by imposing a retreat of criminal provisions. Third, the imposition of retroactive criminal provisions is basically prohibited in criminal law because it is contrary to the soul and the foundation of the criminal law that is the principle of legality but the enforcement of retroactive

50 Mark M. Lanier and Stuart Penry, Essential Criminology, (Florida Unites States of America: Westview Press, 2010), p., 206. 


\section{Hariman Satria}

criminal provisions can be accepted with the aim of upholding justice. Strictly for the sake of the principle of justice, the principle of legality can be misused.

Fourth, the deviation of the principle of legality by emphasizing the fulfillment of the principle of justice, in theory, finds empirical justification on the grounds that the law can not be applied if there is an inconsistency between the law and justice. Fifth, in the context of international criminal law, the enforcement of retroactiveness of criminal law on the grounds of justicehas also been presented in the Nurenberg Court or London Charter and the Tokyo Court where perpetrators of w ar crimes are tried under the retroactive law. The Court is of the opinion that a convict by violating the principle of legality is unfair but does not punish the guilty person for the crimes he committed much more unfairly. Sixth, as a suggestion that in the anti-terrorism rules should the formation of Act strictly formulate criminal act, criminal responsibility refers to the principle of legality so as not to cause deep debate when it will be applied in the field. In addition, by firmly accommodating the principle of legality it can avoid the impression of unfair prejudice and arbitrary processes.

\section{References}

Adji, Indriyanto Seno, Revisi UU Terorisme, Penegakan Hukum dan Perlindungan HAM, KOMPAS, Minggu, 17 Juli 2016.

Atmasasmita, Romli, Pengantar Hukum Pidana Internasional Bandung: Refika Aditama, 2003.

Bantekas, Ilias, and Nash, Susan, International Criminal Law, New York: Routledge-Cavendish, 2007.

Bassiouni, M. Cherif, Introduction to International Criminal Law, New York: Transnational Publishers Ardsley, 2003.

Boot, Machteld, Nullum Crimen Sine Lege and the Subject Matter Jurisdiction of the International Criminal Court: Genocide, Crimes Against Humanity, War Crimes, New York: Intersentia, Antwerpen-Oxford, 2001.

Cassese, Antonio, International Criminal Law, New York: Oxford University Press, 2003.

Chamblis, William J dan Hass, Aida Y, Criminology: Connecting Theory, Research $\mathcal{E}$ Practice, New York: McGraw-Hill, 2012.

Combss, Cindy C., and Slann, Martin, Encyclopedia of Terrorism, New York: Facts on File Library, 2007. 
El-Dakkak, M. Shokry, State's Crimes Against Humanity: Genocide, Deportation and Torture form The Perspectives of International and Islamic Laws, Kuala Lumpur: A.S. Noordeen, 2000.

Gurule, Jimmy dan Corn, Geoffrey S, Principle of Counter-Terrorism Law, New York: West A Thomson Reuters Bussines, 2011.

Hagan, Frank E, Introduction to Criminology: Theories, Methods, and Criminal Behavior, London: Sage Publication, 2012.

Hamzah, Andi, Perundang-Undangan Pidana Tersendiri-Nonkodifikasi (Jakarta: PT Sofmedia, 2014)

Hiariej, Eddy O.S, Asas Legalitas dan Penemuan Hukum Dalam Hukum Pidana, Jakarta: Erlangga, 2009.

2009.

Pengantar Hukum Pidana Internasional, Jakarta: Erlangga,

Jenkins, Brian, and International Terrorism: A New Kind of Warfare, Santa Monica: Rand Corporation, 1974.

Kadish, Sanford H, Encyclopedia of Crime and Justice, New York-London: The Free Press Collier Macmillan Publishers, 1983.

Krisnaw ati, Dani, et.all, Bunga Rampai Hukum Pidana Khusus, Jakarta: Pena Ilmu dan Amal, 2006.

Lanier, Mark M. and Henry, Stuart, Essential Criminology, Florida Unites States of America: Westview Press, 2010.

Moeljatno, Asas-Asas Hukum Pidana, Jakarta: Rineka Cipta, 2008.

Muladi, Kapita Selekta Sistem Peradilan Pidana (Semarang: Badan Penerbit Universitas Diponegoro, 1995)

Hebert L Packer, The Limits of the Criminal Sanction, New York: Oxford University Press, 1968.

Poernomo, Bambang, Asas-Asas Hukum Pidana, Jakarta: Ghalia Indonesia, 1993.

Poerwadarminta, W.J.S, Kamus Umum Bahasa Indonesia, Jakarta: Balai Pustaka, 1990.

Rawls, John, A Theory of Justice, Massachusetts-New York: Harvard University Press, 1999. 


\section{Hariman Satria}

Remmelink, Jan, Hukum Pidana: Komentar atas Pasal-Pasal Terpenting dari Kitab Undang-Undang Hukum Pidana Belanda dan Padanannya dalam Kitab Undang-Undang Hukum Pidana Indonesia, Jakarta: Gramedia Pustaka Utama, 2003.

Sapardjaja, Komariah Emong, Ajaran Melawan Hukum Materil dalam Hukum Pidana Indonesia: Studi Kasus tentang Penerapan dan Perkembangannya dalam Yurisprudensi, Bandung: Alimni, 2002.

Schaffmeister, D, Keijzer, N, Sutorius, E.PH, Hukum Pidana: Kumpulan Bahan Penataran Hukum Pidana Dalam Rangka Kerjasama Hukum Indonesia Belanda, Yogyakarta: Liberty, 1995.

Sudarto, Kapita Selekta Hukum Pidana, (Bandung: Alumni, 2006)

Sullivan, Larry E. and Rossen, Marie Simonetti, Encyclopedia of Law EnforcementVolume 1, London: Sage Publications, 2005.

Claire de Than and Edwin Shorts, International Criminal Law and Human Rights, London: Sweet and Maxwell, 2003.

Vito, Gennaro F. dan Holmes, Ronald M, Criminology: Theory, Research and Policy, California: Wadsw orth Publishing Company, 1994.

Wright, Richard A. dan Miller, J. Mitchel, Encyclopedia of Criminology, New York: Routledge Taylor and Francis Group, 2005.

Yunus, Nur Rohim, Restorasi Budaya Hukum Masyarakat Indonesia, Bogor: Jurisprudence Press, 2012.

www.tempo.co.id, 10 (sepuluh) Organisasi Teroris Paling Berbahaya di Dunia, retrieved on March 20th 2015.

http://www.bbc.com/indonesia/dunia/2016/07/160714 dunia nice serangan ob ama, retrieved on July 30th, 2016. 